\title{
Relating physical properties to temperature-induced damage in carbonate rocks
}

\author{
F. VAGNON*, C. COLOMBERO $\dagger$, C. COMINA \\ S. C. VINCIGUERRA**
}

\begin{abstract}
Carbonate rocks have a widespread diffusion in the Earth crust and are extensively used in cultural heritage and buildings. These rocks can be naturally or anthropically exposed to high temperatures. Consequently, relating physical properties to temperature-induced damage is extremely important. Six sets of compositionally and texturally different carbonate rocks, spanning from limestones and marbles to dolomitic marbles, were analysed in this study. Different physical properties, such as porosity, seismic wave velocities and electrical resistivity, were measured before and after thermal treatments with heating/cooling ranges between 105 and $600^{\circ} \mathrm{C}$. Microstructural observations and optical analyses were used to investigate how temperature-induced damage affects the physical measured properties of the different microstructures. This integrated approach allowed to define a generalised relationship between physical properties and thermal-induced damage, by way of an induced damage index valid for a broad suite of carbonate rocks.
\end{abstract}

KEYWORDS: geophysics; rocks/rock mechanics; temperature effects

Published with permission by the ICE under the CC-BY 4.0 license. (http://creativecommons.org/licenses/by/4.0/)

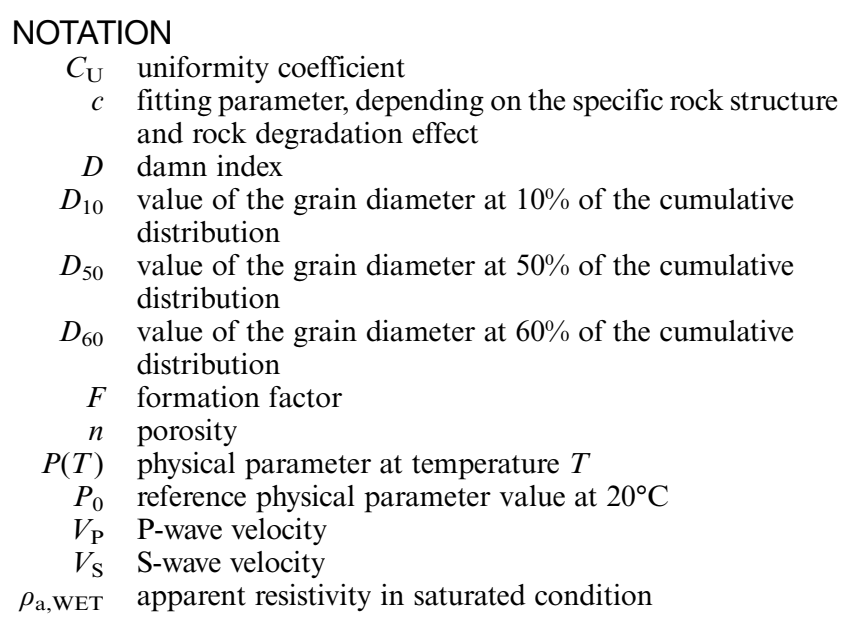

Manuscript received 14 September 2020; first decision 27 January 2021; accepted 1 March 2021.

Published online at www.geotechniqueletters.com on 4 May 2021.

*Department of Earth Sciences, Università di Torino, Torino, Italy (Orcid:0000-0003-0539-0557).

†Department of Environment, Land and Infrastructure Engineering, Politecnico di Torino, Torino, Italy

(Orcid:0000-0001-9818-7464).

Department of Earth Sciences, Università di Torino, Torino, Italy (Orcid:0000-0002-3536-9890).

$\S$ Department of Earth Sciences, Università di Torino, Torino, Italy (Orcid:0000-0001-8422-6303).

|Interuniversity Department of Regional and Urban Studies and Planning, Torino, Italy (Orcid:0000-0002-5397-9377).

qUniversidade Estadual Norte Fluminense - Darcy Ribeiro/UENF, Laboratorio de Engenharia e Exploração de Petroleo/LENEP, Macaé - RJ - Brasil (Orcid:0000-0001-6284-6755).

**Department of Earth Sciences, Università di Torino, Torino, Italy (Orcid:0000-0002-6939-3549).

\author{
$\rho_{\text {fluid }}$ resistivity of the saturating fluid \\ $\sigma \quad$ standard deviation
}

\section{INTRODUCTION}

High-temperature gradients drive mechanisms of degradation and weakening of rocks, thus controlling a number of geological processes, engineering applications and cultural heritage (Vagnon et al., 2019 and references therein).

Among various rocks, carbonates are widespread diffused and are extensively used in cultural heritage artefacts and buildings. Large crustal volumes of carbonate rocks are naturally exposed to significant temperature increases in areas with anomalous geothermal gradients. The exposure to high temperatures could also be related to engineering applications. Forecasting their physical evolution under temperature gradients is therefore of utmost importance for many fields of rock mechanics.

While numerous studies have investigated the damageinduced processes by temperature effects on carbonate rocks (Heap et al., 2013; Castagna et al., 2018 and reference therein), less attention has been paid to quantitatively generalise throughout physical parameters evolution of the thermal degradation induced by heating.

A relationship linking physical parameters and temperature (thermal degradation relationship) has been proposed by several authors (e.g. Koca et al., 2006; Dwivedi et al., 2008; Zhao et al., 2012; Musso et al., 2015; Weydt et al., 2018; Vagnon et al., 2019) under the form:

$$
P(T)=P_{0} \mathrm{e}^{ \pm c T}
$$

where $P(T)$ is a given physical parameter at temperature $T$, $P_{0}$ is its reference value at $20^{\circ} \mathrm{C}$ and $c$ is a fitting parameter, depending on the specific rock structure and rock degradation effect. The sign of the exponent is positive if the considered parameter increases with temperature (negative otherwise). Based on experimental tests, several authors 
(Koca et al., 2006; Dwivedi et al., 2008; Zhao et al., 2012; Vagnon et al., 2019) have proposed similar exponential equations for the thermal degradation relationship with a different $c$ fitting parameter.

This study has the main objective of defining a general relationship between physical properties and thermal-induced damage, by way of a multiparametricinduced damage index valid for a broad suite of carbonate rocks.

Six sets of different carbonate rock specimens were tested before and after thermal treatment, with heating/cooling cycles from 105 to $600^{\circ} \mathrm{C}$. Density in dry and saturated conditions, porosity, ultrasonic pulse velocity (UPV) and electrical resistivity (ER) were measured. Microstructural observations and both grain-size distribution curves and crack densities were analysed. A unified multiparametric thermally induced damage coefficient was quantified to provide a general law for carbonate rocks.
SAMPLE SETS AND EXPERIMENTAL METHODS

Cylindrical samples obtained from the four different sampling areas (Fig. 1), were classified into six sets:

- Seven limestone samples, coming from the fossil hydrothermal system of Las Minas (Mexico), named 'RLM' in the following.

- Ten dolomitic marble samples, coming from Granados Quarry (Tatatila, Mexico), named 'GQ'.

- Eleven marble samples, coming from San Lorenzo Quarry (Italy), named 'Valdieri'.

- Eighteen marble samples, coming from Italva Basin (Brazil), divided into three subsets (of six specimens, respectively) and named 'Brazil C', 'Brazil D' and 'Brazil SJ'.

Samples diameter ranged from 40 to $50 \mathrm{~mm}$, and the average length of $95 \mathrm{~mm}$. Samples followed the geometric

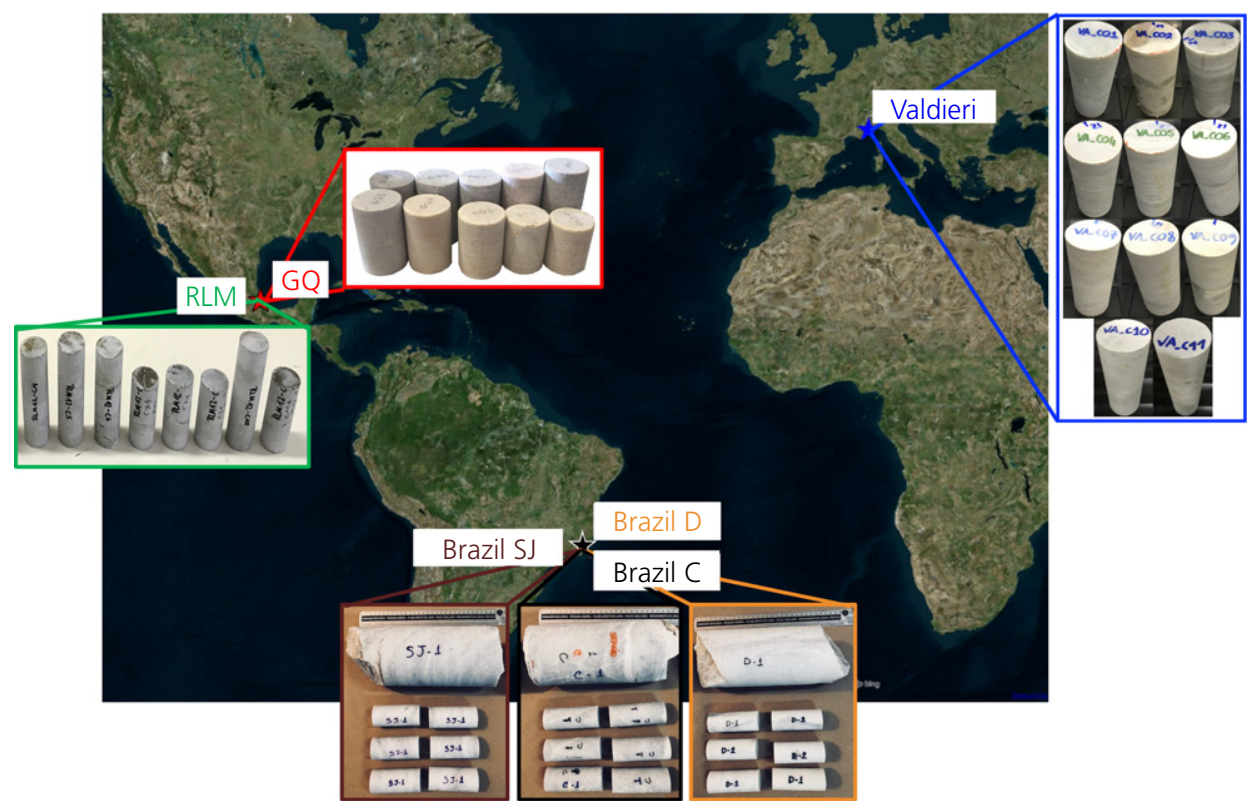

Fig. 1. Location of the four sampling areas and pictures of the different sets of specimens

Table 1. Percentage of mineral compounds and oxides retrieved from XRD and XRF analyses

\begin{tabular}{|c|c|c|c|c|c|c|c|}
\hline & \multirow[t]{2}{*}{ Compound name } & RLM & GQ & Valdieri & Brazil C & Brazil D & Brazil SJ \\
\hline & & \multicolumn{6}{|c|}{ Concentration: $\%$} \\
\hline \multirow[t]{8}{*}{ XRD } & Calcite & $97 \cdot 3$ & - & 98 & $37 \cdot 9$ & 48.98 & $14 \cdot 84$ \\
\hline & Quartz & $2 \cdot 7$ & - & - & - & - & - \\
\hline & Dolomite & - & 100 & 2 & $42 \cdot 58$ & $42 \cdot 46$ & $73 \cdot 33$ \\
\hline & Forsterite & - & - & - & 18 & - & - \\
\hline & Tremolite & - & - & - & $1 \cdot 47$ & - & $2 \cdot 02$ \\
\hline & Wairauite & - & - & - & $0 \cdot 05$ & - & $4 \cdot 61$ \\
\hline & Siderite & - & - & - & - & - & $5 \cdot 18$ \\
\hline & Olivine & - & - & - & - & $8 \cdot 1$ & - \\
\hline \multirow[t]{9}{*}{ XRF } & Magnesium oxide & $1 \cdot 106$ & $36 \cdot 331$ & $2 \cdot 05$ & $17 \cdot 33$ & $20 \cdot 39$ & $21 \cdot 36$ \\
\hline & Calcium oxide & $96 \cdot 529$ & $62 \cdot 495$ & $97 \cdot 02$ & $78 \cdot 84$ & $67 \cdot 37$ & $76 \cdot 45$ \\
\hline & Silicon dioxide & $1 \cdot 047$ & $0 \cdot 48$ & $0 \cdot 425$ & $3 \cdot 65$ & $11 \cdot 36$ & $1 \cdot 898$ \\
\hline & Aluminium oxide & $0 \cdot 356$ & $0 \cdot 118$ & $0 \cdot 18$ & - & 0.54 & - \\
\hline & Potassium oxide & $0 \cdot 33$ & $0 \cdot 195$ & - & - & - & - \\
\hline & $\mathrm{F}$ & $0 \cdot 3$ & - & - & - & - & - \\
\hline & $\mathrm{CoO}$ & - & $0 \cdot 149$ & - & $0 \cdot 014$ & - & $0 \cdot 006$ \\
\hline & Ferric oxide & $0 \cdot 131$ & - & $0 \cdot 13$ & $0 \cdot 05$ & $0 \cdot 26$ & $0 \cdot 17$ \\
\hline & Others & $0 \cdot 21$ & $0 \cdot 233$ & $0 \cdot 195$ & $0 \cdot 104$ & $0 \cdot 0725$ & $0 \cdot 107$ \\
\hline
\end{tabular}


requirements for standard determination of the analysed physical properties.

To analyse the chemical content of each set, $\mathrm{x}$-ray fluorescence (XRF) and x-ray diffraction (XRD) analyses were conducted (Table 1). It can be observed that RLM and Valdieri samples are mostly calcitic $(97 \cdot 3$ and $98 \%$, respectively) while GQ samples are essentially dolomitic. Brazilian samples show transitional compositions between these end members.

Following the experimental procedure detailed in Vagnon et al. (2019), density in dry and saturated conditions, porosity $(n), \mathrm{P}$ - and S-wave velocity $\left(V_{\mathrm{P}}\right.$ and $\left.V_{\mathrm{S}}\right)$ and ER (in saturated conditions, $\rho_{\mathrm{a}, \mathrm{WET}}$ ) of the 46 core specimens were measured before and after heating (at target

Table 2. Experimental instruments, international standards and main physical parameters

\begin{tabular}{|c|c|c|c|}
\hline Physical property & International standard & Test instrument & Technical parameters \\
\hline $\begin{array}{l}\text { Density in dry and } \\
\text { saturated conditions, } \\
\text { Porosity }\end{array}$ & $\begin{array}{l}\text { ISRM (1979). Suggested methods for } \\
\text { determining water content, porosity, density, } \\
\text { absorption and related properties and swelling } \\
\text { and slake-durability index properties. } 1977\end{array}$ & Caliper Analytical balance & $\begin{array}{l}\text { Resolution: } 0 \cdot 0002 \mathrm{~m} \\
\text { Resolution: } 0 \cdot 0001 \mathrm{~kg}\end{array}$ \\
\hline $\begin{array}{l}\text { P- and S-wave velocity, } \\
V_{\mathrm{P}} \text { and } V_{\mathrm{S}}\end{array}$ & ASTM D 2845-08 (ASTM, 2008) & $\begin{array}{l}\text { Ultrasonic pulse generation } \\
\text { and acquisition system } \\
\text { (Pundit Lab, Proceq) }\end{array}$ & $\begin{array}{l}\text { Two cylindrical } 250-\mathrm{kHz} \\
\text { tx-rx probes }\end{array}$ \\
\hline $\begin{array}{l}\text { ER measurement, } \\
\rho_{\text {app_dry }}\end{array}$ & 一 & $\begin{array}{l}\text { Syscal-Pro (Iris instruments) } \\
\text { acquisition system }\end{array}$ & $\begin{array}{l}\text { On-purpose built } \\
\text { measuring quadrupole } \\
\text { (Vagnon et al., 2019) }\end{array}$ \\
\hline Heat treatment & 一 & $\begin{array}{l}\text { Carbolite Temperature } \\
\text { programmer Eurotherm } \\
\text { 2416CG } \\
\text { XRF: S2 Ranger (Bruker } \\
\text { Company) }\end{array}$ & $\begin{array}{l}\text { Temperature range: } \\
\quad 1100^{\circ} \mathrm{C} \\
\text { Heating rate: } 0 \cdot 06^{\circ} \mathrm{C} / \mathrm{s} \\
\text { Resolution: } 1^{\circ} \mathrm{C}\end{array}$ \\
\hline
\end{tabular}

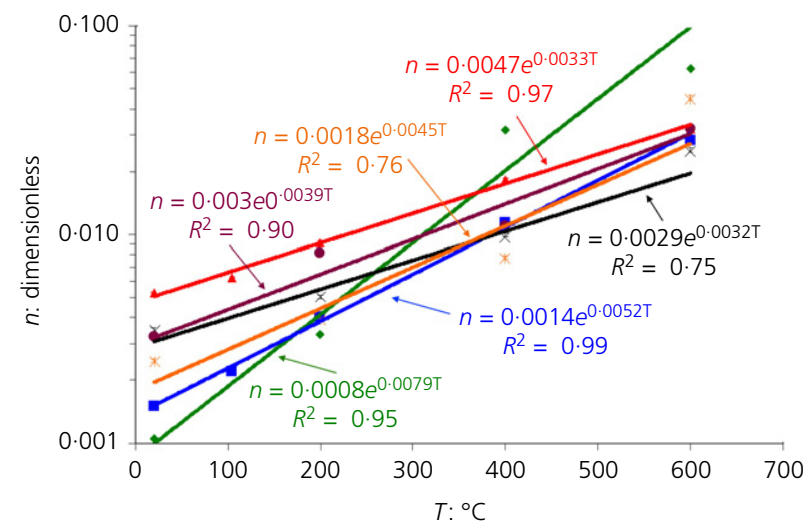

(a)

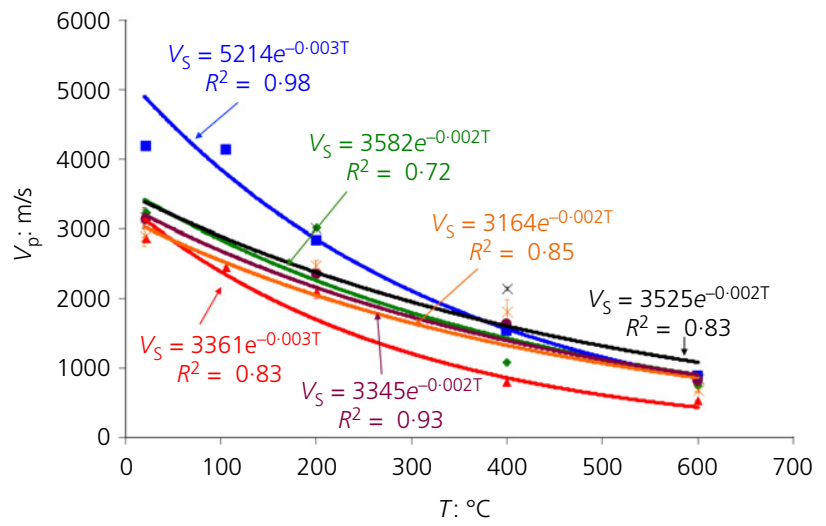

(c)

$\bullet$ RLM Valdieri $\triangle \mathrm{GQ} \times$ Brazil C

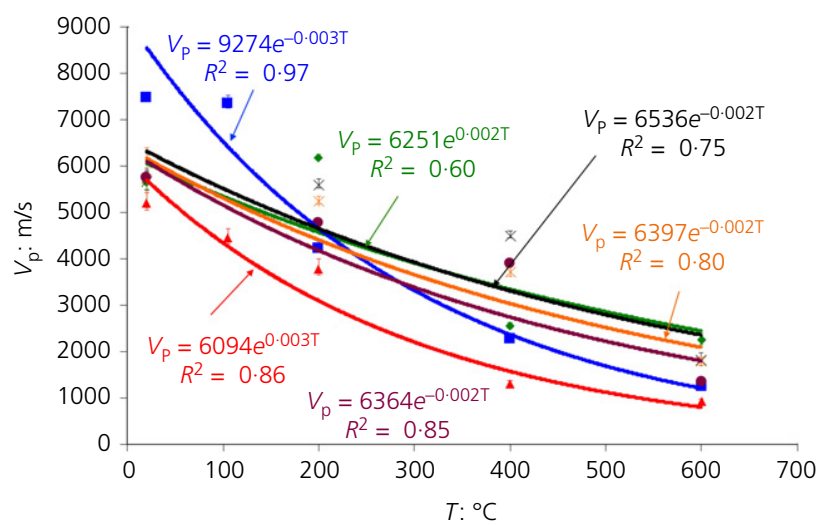

(b)

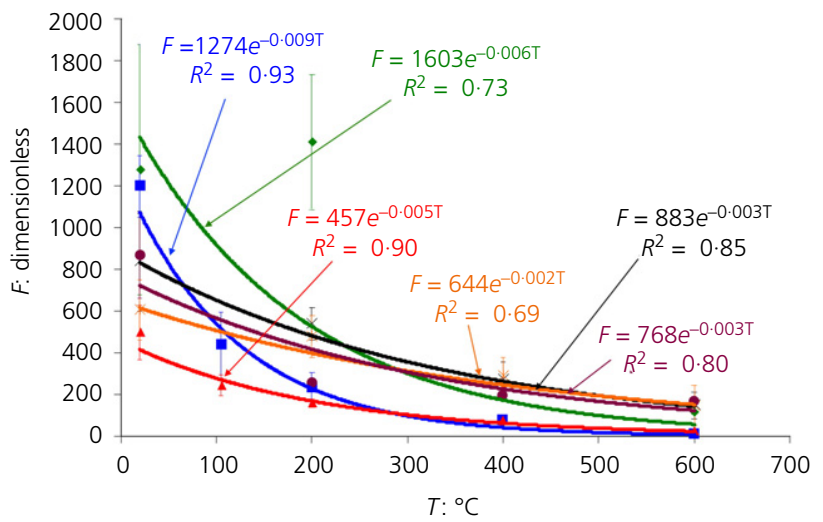

(d)

Fig. 2. Relationship between (a) porosity; (b) P-wave velocity; (c) S-wave velocity and (d) formation factor and temperature for the studied samples. All the data are associated to their standard deviations: where not visible, the length of the error bars is lower than the marker size 
temperatures of $105,200,400$ and $600^{\circ} \mathrm{C}$, respectively). Table 2 summarises the measured parameters, the international standards and experimental methodologies adopted for their determination. The thermal treatment involved a three-stage procedure (Vagnon et al., 2019): (a) sample heating up to the target temperature with a heating rate of $0.06^{\circ} \mathrm{C} / \mathrm{s} ;(b) 24 \mathrm{~h}$ sample exposure to constant target temperature; $(c)$ slow-rate sample cooling down to room temperature (one day on average). The exposure time allows the uniform heating of the samples, ensuring that the surface temperature was the same inside the

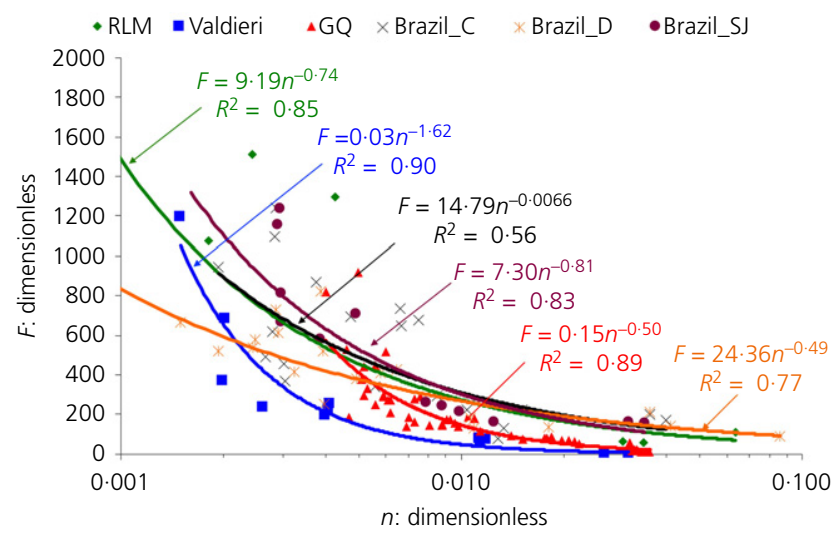

Fig. 3. Relationship between formation factor and porosity for the studied samples. All the data are associated to their standard deviations: where not visible, the length of the error bars is lower than the marker size

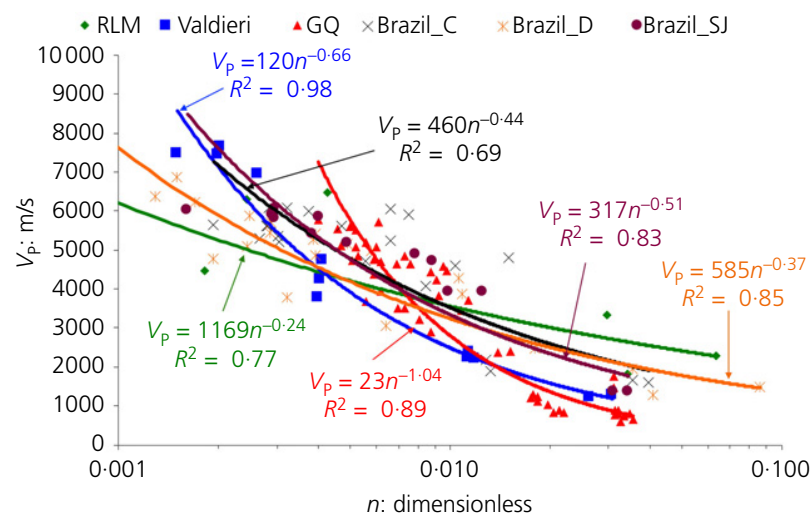

(a)

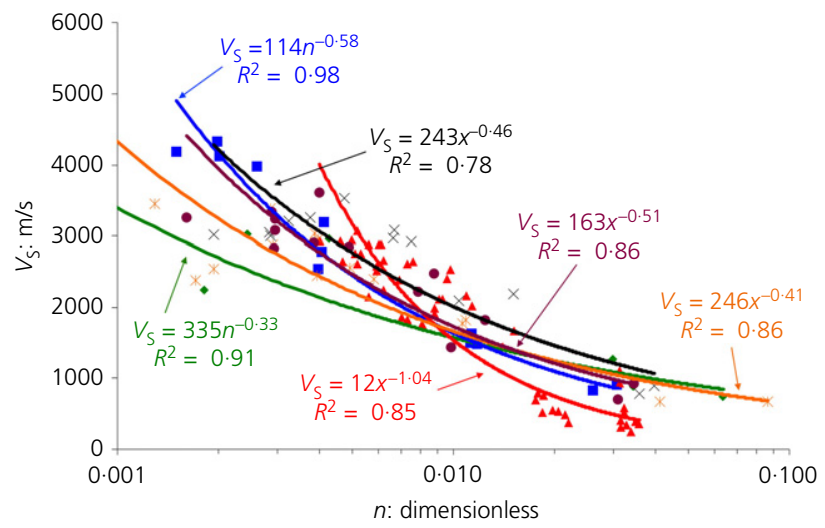

(b)

Fig. 4. Relationship between $\mathrm{P}$-wave (a) and S-wave (b) velocity and porosity for the studied samples sample. Even in cooling phase, the time inside the furnace prevents thermal shocks that may influence the sample physical properties, by increasing the thermal degradation effects.

Values of $\rho_{\mathrm{a}, \mathrm{WET}}$ were also expressed in terms of formation factor, $F$ (Archie, 1942), a dimensionless parameter that represents the ratio between $\rho_{\mathrm{a}, \mathrm{WET}}$ and the saturating fluid resistivity, $\rho_{\text {fluid. }}$.

To analyse the main effects of thermal treatment on the micro-structure of the studied carbonate rocks, $20 \times 40 \mathrm{~mm}$ thin sections were obtained from natural and thermal-treated extra-samples belonging to the different

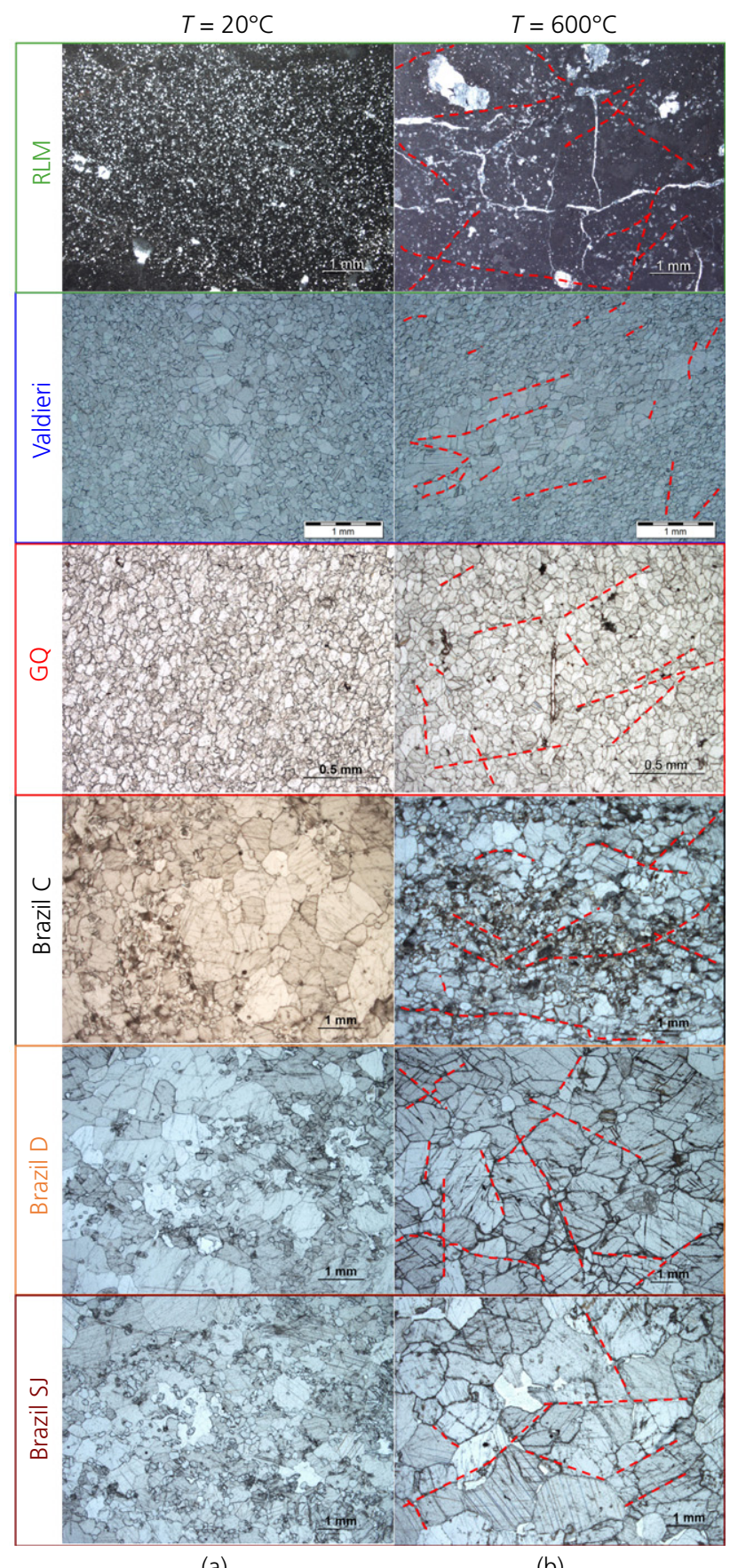

(a)

(b)

Fig. 5. Optical microscope observations of specimens at $20^{\circ} \mathrm{C}$ (left column) and at $600^{\circ} \mathrm{C}$ (right column) and highlight of major thermal cracks generated after thermal treatment (red dashed lines) 
sets. Microstructural observations were then performed using a transmitted polarised light microscope. By using the image processing program ImageJ (Schneider et al., 2012), the pre- and post-heating grain-size distribution and crack length (Arganda-Carreras et al., 2010) were measured on thin sections. Crack density, expressed as the ratio between total cracks length and area investigated, was also proposed as a parameter for evaluating thermal damage.

\section{RESULTS}

Physical parameter measurements

The thermal treatment induced significant changes in physical properties such as $n$, UPV and $\rho_{\text {a,WET values for }}$ each set of specimens. In Appendix A and Fig. 2 all data are shown. Exponential relationships were fitted to all parameters for each data set, except density values which do not exhibit a clear dependence to the temperature, in agreement with other previous findings (Ferrero \& Marini,

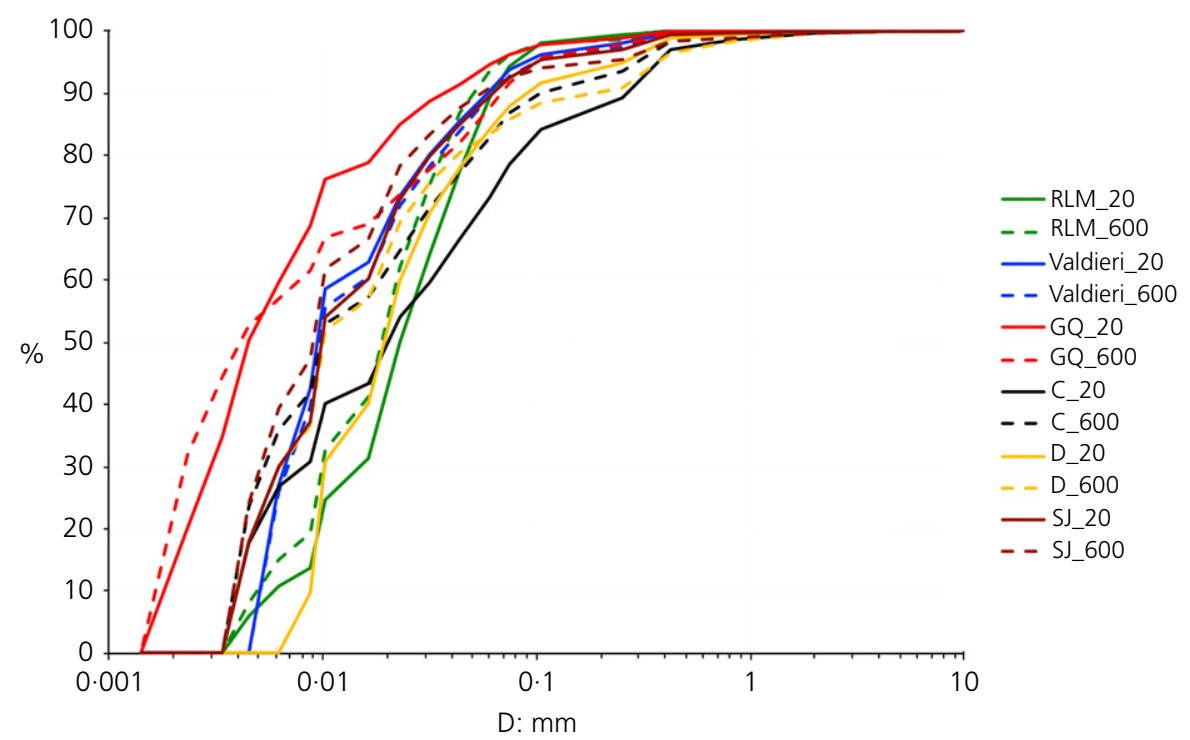

(a)

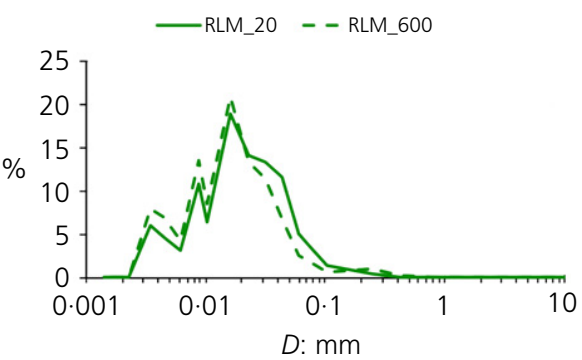

(b)

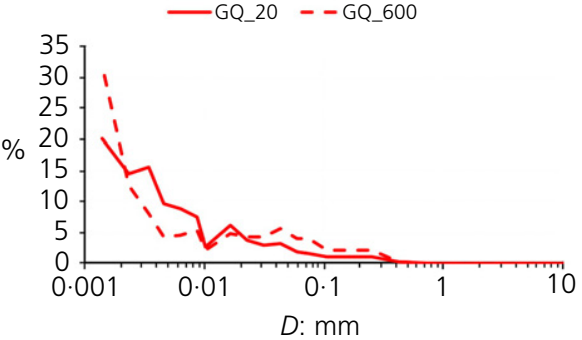

(d)

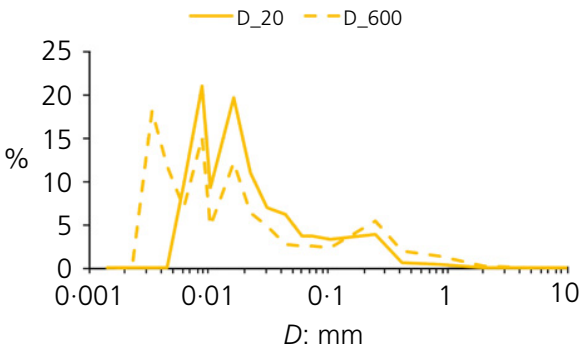

(f)

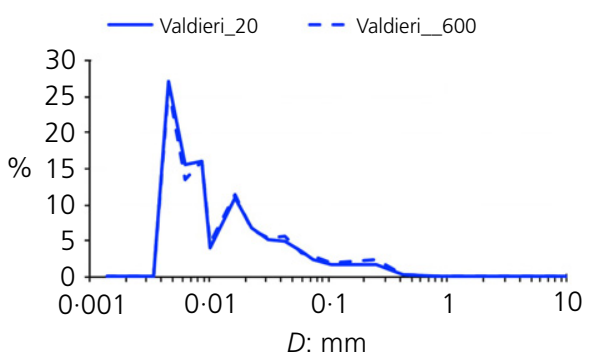

(c)

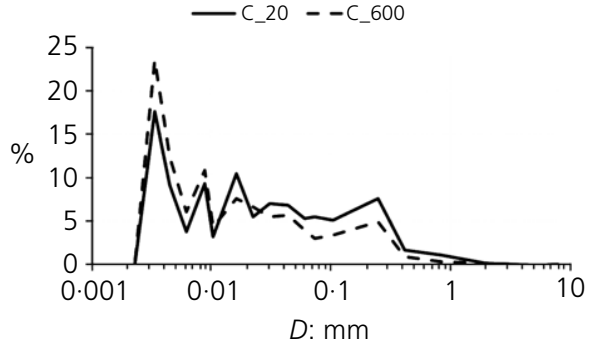

(e)

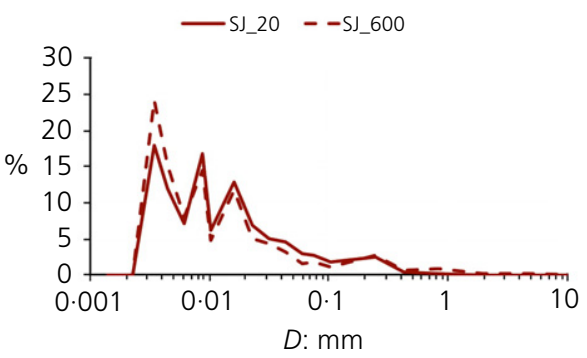

(g)

Fig. 6. Cumulative (a) and derivative (b to $\mathrm{g}$ for each sample) grain-size distributions of microphotographs at $20^{\circ} \mathrm{C}$ (continuous lines) and at $600^{\circ} \mathrm{C}$ (dashed lines) 
2000; Koca et al., 2006; Yavuz \& Topal, 2007; Peng et al., 2016; Su et al., 2018; Vagnon et al., 2019).

Porosity (Fig. 2(a)) showed an exponential trend with temperature for each set of specimens. In particular, the porosity of RLM limestones was more sensitive to temperature gradients than the other sets of tested specimens.

In general, all the sample sets exhibited the same trends of $V_{\mathrm{P}}$ and $V_{\mathrm{S}}$ with increasing target temperature (Figs. 2(b) and 2(c)), but with initial $\mathrm{P}$ - and S-wave velocity values significantly different.

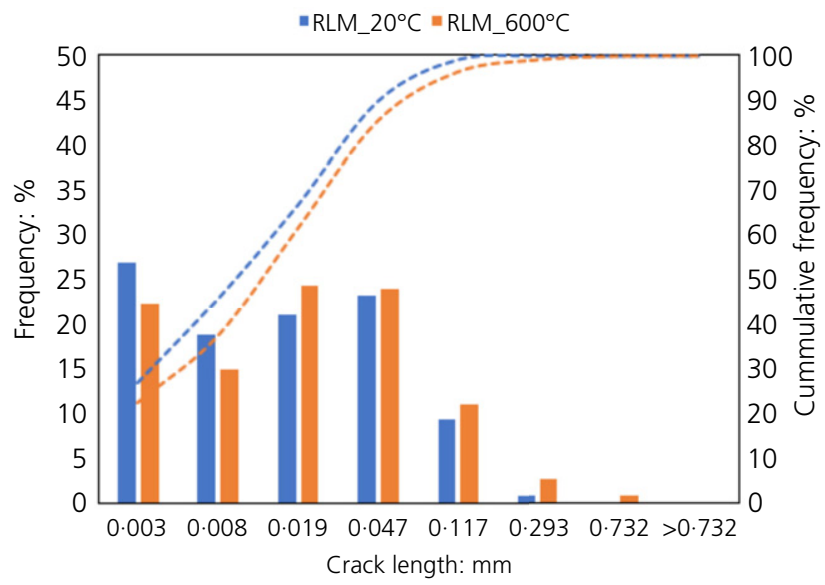

(a)

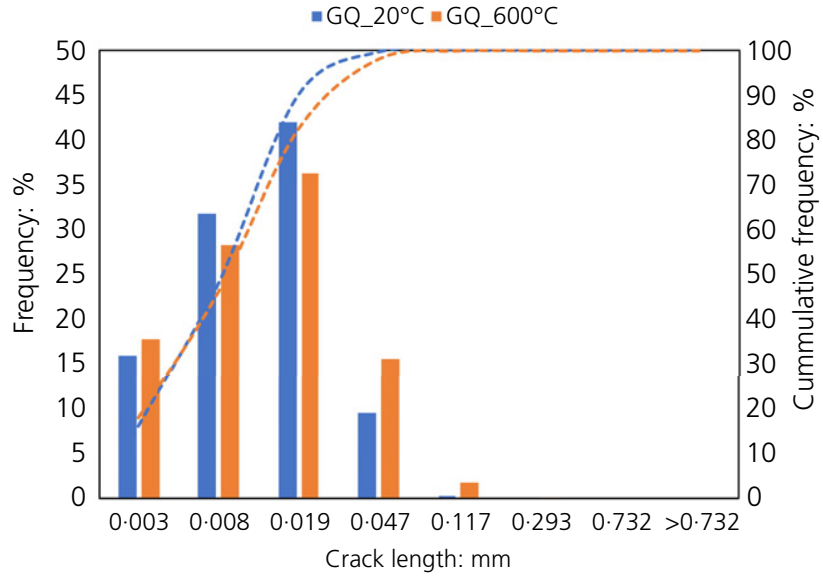

(c)

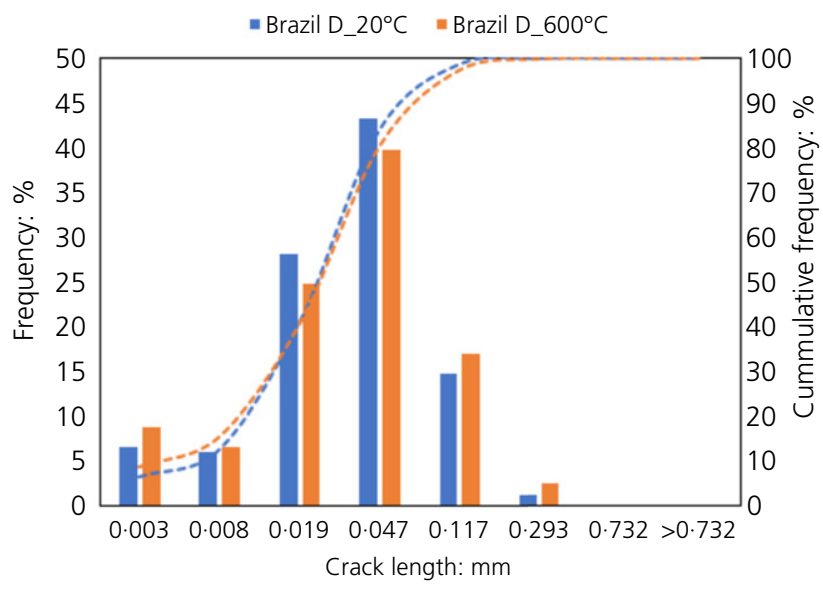

(e)
The formation factor values $(F)$ of each individual set of rock samples is reported in Fig. 2(d). A clear modification in electrical properties is found between different rock samples, with increasing target temperature. In particular, $F$ clearly decreased by increasing temperature.

\section{Discussion and relationships between physical parameters}

The previous section has highlighted a strong dependence of each single physical parameter on temperature, repeatable

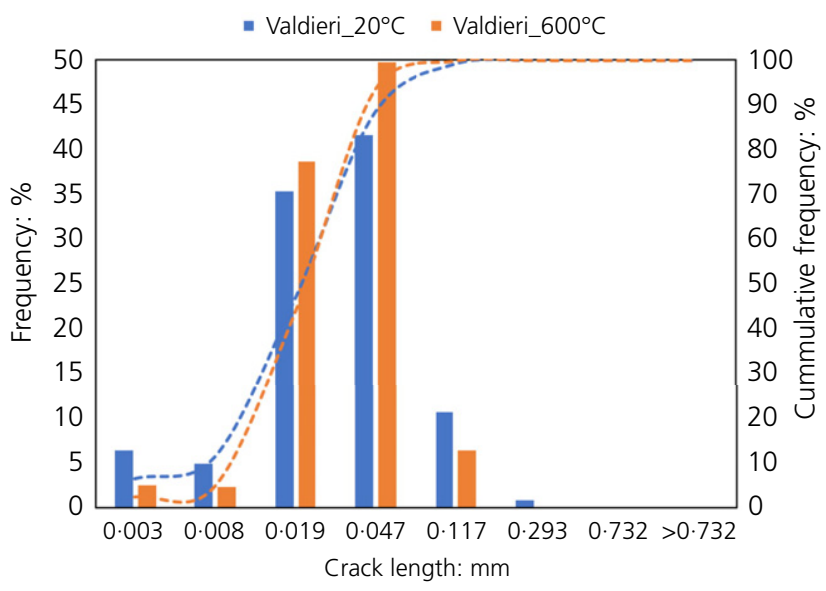

(b)

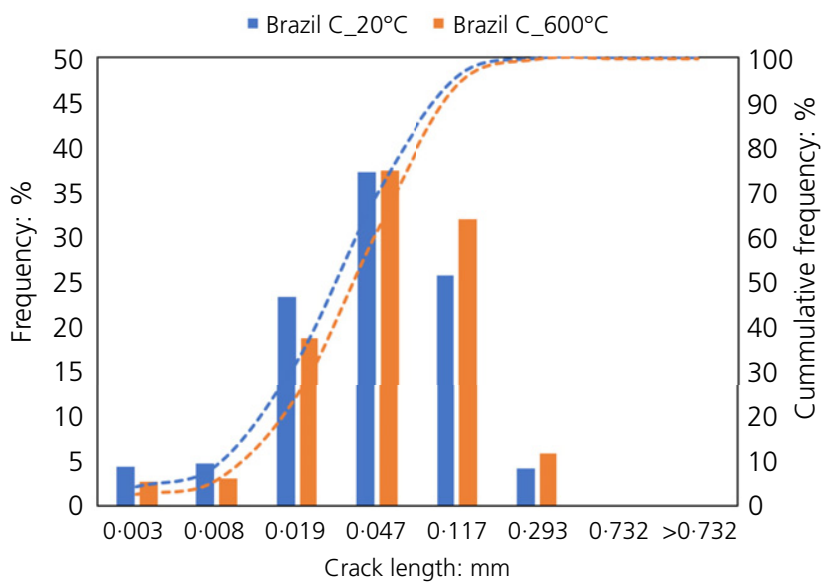

(d)

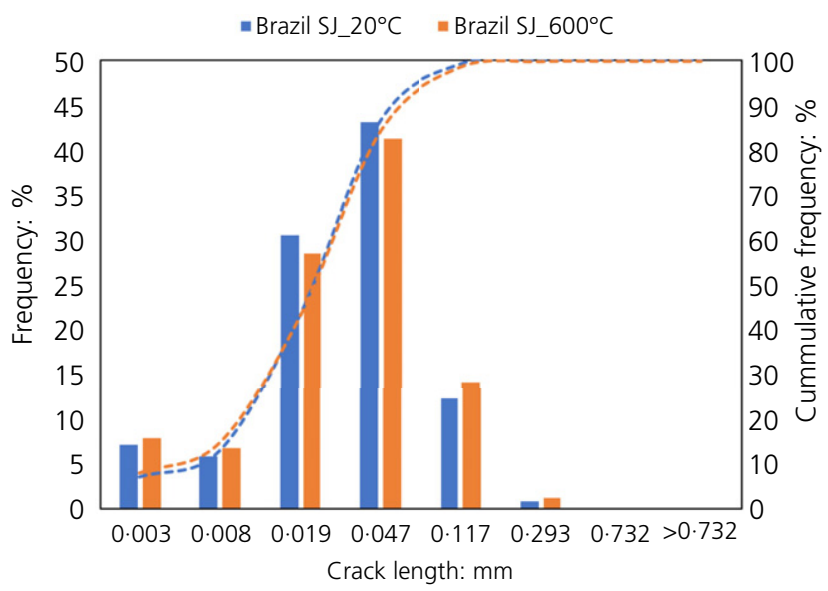

(f)

Fig. 7. Frequency (column bars) and cumulative (dashed lines) distribution of crack length for each sample at $20^{\circ} \mathrm{C}$ (blue) and at $600^{\circ} \mathrm{C}$ (orange) for each analysed sample (a) to (f) 
Table 3. Summary of grain-size distribution performed on micrographs of the tested rocks

\begin{tabular}{l|r|l|l}
\hline Set & $T:{ }^{\circ} \mathrm{C}$ & $D_{50}: \mathrm{mm}$ & $C_{\mathrm{U}}:-$ \\
\hline RLM & 20 & $0 \cdot 0227$ & $5 \cdot 05$ \\
& 600 & $0 \cdot 019$ & $5 \cdot 04$ \\
Valdieri & 20 & $0 \cdot 009$ & $2 \cdot 20$ \\
& 600 & $0 \cdot 009$ & $3 \cdot 26$ \\
GQ & 20 & $0 \cdot 0045$ & $3 \cdot 65$ \\
& 600 & $0 \cdot 004$ & $5 \cdot 80$ \\
Brazil C & 20 & $0 \cdot 0227$ & $6 \cdot 96$ \\
Brazil D & 600 & $0 \cdot 01$ & $4 \cdot 44$ \\
\multirow{3}{*}{ Brazil SJ } & 20 & $0 \cdot 019$ & $2 \cdot 61$ \\
& 600 & $0 \cdot 01$ & $4 \cdot 22$ \\
& 20 & $0 \cdot 0102$ & $3 \cdot 62$ \\
& 600 & $0 \cdot 0087$ & $2 \cdot 27$ \\
\hline
\end{tabular}

Table 4. Summary of crack length results performed on micrographs of the tested rocks

\begin{tabular}{|c|c|c|c|c|c|}
\hline \multirow[t]{2}{*}{ Set } & \multirow[t]{2}{*}{$T:{ }^{\circ} \mathrm{C}$} & \multicolumn{3}{|c|}{ Crack length: mm } & \multirow{2}{*}{$\begin{array}{r}\text { Crack } \\
\text { density } \\
1 / \mathrm{mm}\end{array}$} \\
\hline & & Min & $\operatorname{Max}$ & Median & \\
\hline \multirow[t]{2}{*}{ RLM } & 20 & $0 \cdot 003$ & $0 \cdot 219$ & $0 \cdot 009$ & $32 \cdot 376$ \\
\hline & 600 & 0.003 & $0 \cdot 898$ & $0 \cdot 012$ & $42 \cdot 015$ \\
\hline \multirow[t]{2}{*}{ Valdieri } & 20 & $0 \cdot 003$ & $0 \cdot 303$ & $0 \cdot 020$ & $28 \cdot 896$ \\
\hline & 600 & $0 \cdot 003$ & $0 \cdot 258$ & $0 \cdot 024$ & $37 \cdot 444$ \\
\hline \multirow[t]{2}{*}{ GQ } & 20 & $0 \cdot 001$ & $0 \cdot 090$ & $0 \cdot 008$ & $47 \cdot 362$ \\
\hline & 600 & $0 \cdot 001$ & $0 \cdot 136$ & $0 \cdot 008$ & $49 \cdot 994$ \\
\hline \multirow[t]{2}{*}{ Brazil C } & 20 & $0 \cdot 003$ & 0.672 & $0 \cdot 029$ & $12 \cdot 195$ \\
\hline & 600 & $0 \cdot 003$ & $0 \cdot 553$ & $0 \cdot 036$ & $16 \cdot 182$ \\
\hline \multirow[t]{2}{*}{ Brazil D } & 20 & $0 \cdot 003$ & 0.603 & $0 \cdot 022$ & $14 \cdot 120$ \\
\hline & 600 & $0 \cdot 003$ & $0 \cdot 739$ & $0 \cdot 023$ & $15 \cdot 560$ \\
\hline \multirow[t]{2}{*}{ Brazil SJ } & 20 & $0 \cdot 003$ & $0 \cdot 552$ & $0 \cdot 021$ & $12 \cdot 444$ \\
\hline & 600 & $0 \cdot 003$ & $0 \cdot 718$ & 0.022 & $15 \cdot 951$ \\
\hline
\end{tabular}

for all lithologies investigated. The main findings can be summarised as follows:

- The thermal treatment induced a moderate increase in porosity due to generation of new cracks or re-opening of existing ones at temperatures up to $550^{\circ} \mathrm{C}$. At higher temperatures, the porosity increase was likely related to decalcination and decarbonation, leading to increased pore space due to the combination of grain comminution and crack damage (Heap et al., 2013). RLM samples showed a more marked increment in porosity compared to the other samples mirroring the fact that limestones undergo more pronounced textural changes, while marbles, already exposed to high temperatures in their formation history that has led to recrystallisation, maintain a memory of the thermal stresses.

- The increase in porosity is mirrored by a decrease in $\mathrm{P}$ - and S-wave velocity and resistivity. With respect to this Valdieri samples showed a slightly different behaviour, since velocities remained relatively constant until $200^{\circ} \mathrm{C}$ with a significant increase only for higher temperatures. This can be correlated to the presence of dolomite that has been observed (Heap et al., 2013) to strengthen rocks at low temperatures, while decarbonation leads to degradation at higher temperatures.

- Figures 3 and 4 show the inverse power-law relationships between physical parameters and porosities. For the $n-V_{\mathrm{P}}$ and $n-V_{\mathrm{S}}$ relationships, the general degradation of physical parameters also influenced the mechanical characteristics of rock samples. For $n-F$ relationship that represents Archie's law, the determined parameters for the power law are not in agreement with typical observed values for carbonate rocks (e.g. Ara et al., 2001).

However, the application of this relationship to carbonate rocks has been already recognised to be difficult due to the complexity of their voids space (e.g. Talabani et al., 2000).

\section{Microstructural observations}

Even if micrographs of thin sections cannot be considered completely as representative of the whole volume of the analysed rock samples, their analysis can be very important for identifying how micromechanical damage induced by heating took place. In this respect, Fig. 5 shows micrographs of thin sections before (a) and after thermal treatment (b) at the highest temperature - that is, $600^{\circ} \mathrm{C}$, for all lithologies investigated. After heating at $600^{\circ} \mathrm{C}$, grain expansion leading to crack generation along grain boundaries is observable in all the samples (Fig. 5). Grain-size analyses can also be considered as a good indicator of the thermal effects, given that the decalcination process can reduce the average grain size at high temperature (Heap et al., 2013). Moreover, the propagation of intragranular microcracks can have a double effect either on the crushing of existing grains or the increase in void volume. For these reasons, both grain-size distributions (Fig. 6) and crack length (Fig. 7 and Table 4) of each micrograph of Fig. 5 were evaluated using the ImageJ code. Moreover, the values of the grain diameter at $50 \%$ of the cumulative distribution $\left(D_{50}\right)$, the uniformity coefficient $\left(C_{\mathrm{U}}\right)$, obtained as the $D_{60} / D_{10}$ ratio and the crack density were additionally determined (Tables 3 and 4).

The analyses highlighted that:

- The temperature increase generates a shift of the grain-size distributions to smaller values, strengthening the hypothesis of the formation of microcracks inside initial bigger grains.

- RLM and Valdieri samples experienced higher thermal degradation since they exhibit the highest increase in crack density. For RLM samples this is probably due to the fact that limestone underwent deeper textural changes with respect to metamorphic rocks or carbonates already affected by high-temperature gradients and circulation of high-temperature fluids.

\section{TOWARDS A UNIFIED DAMAGE INDEX}

From the above reported results, an induced damage index for carbonate rocks exposed to different temperatures can be proposed. For porosity, the induced damage index can be defined as:

$$
D_{n}=1-\frac{n_{\mathrm{RT}}}{n(T)}
$$

where $D_{n}$ is the induced damage index for porosity, $n_{\mathrm{RT}}$ is the room-temperature porosity and $n(T)$ is the porosity evaluated at the different target temperature.

For the other parameters the induced damage index can be written as

$$
D_{\mathrm{pP}}=1-\frac{P(T)}{P_{0}}
$$

where $D_{\mathrm{P}}$ is the induced damaged index for the generic parameter. 


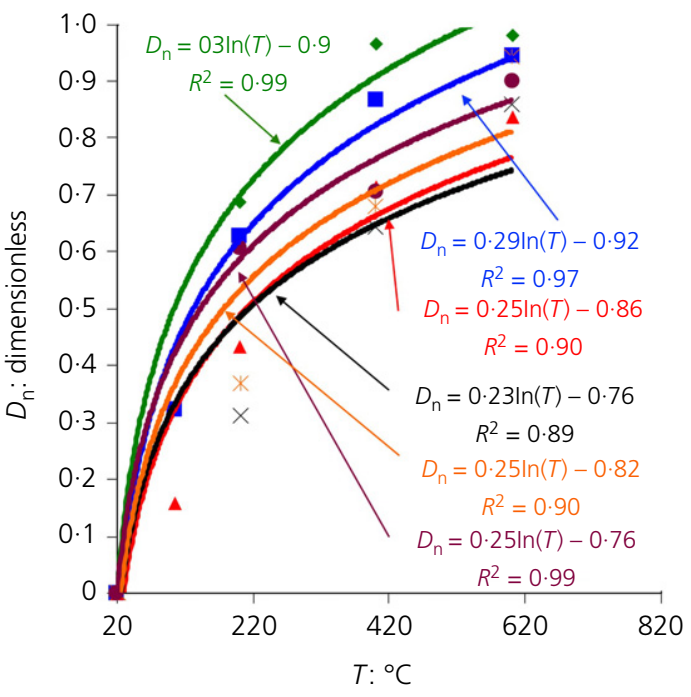

(a)

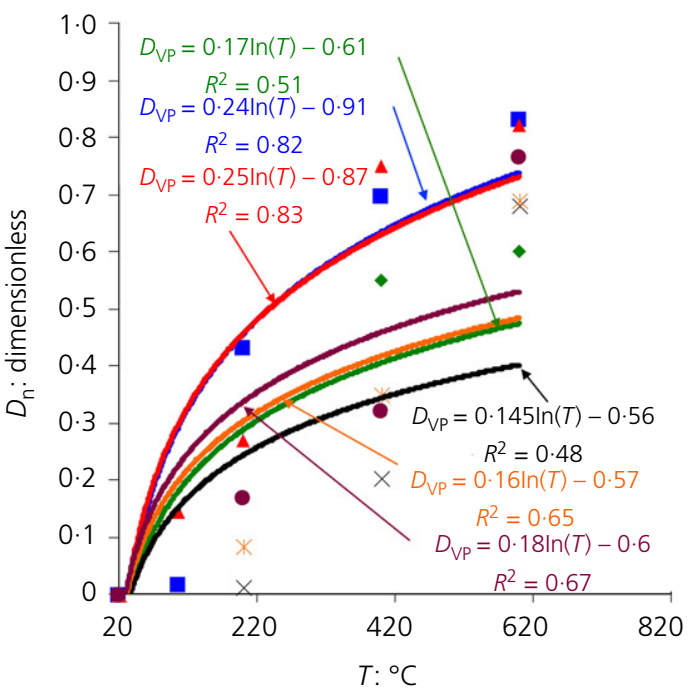

(c)

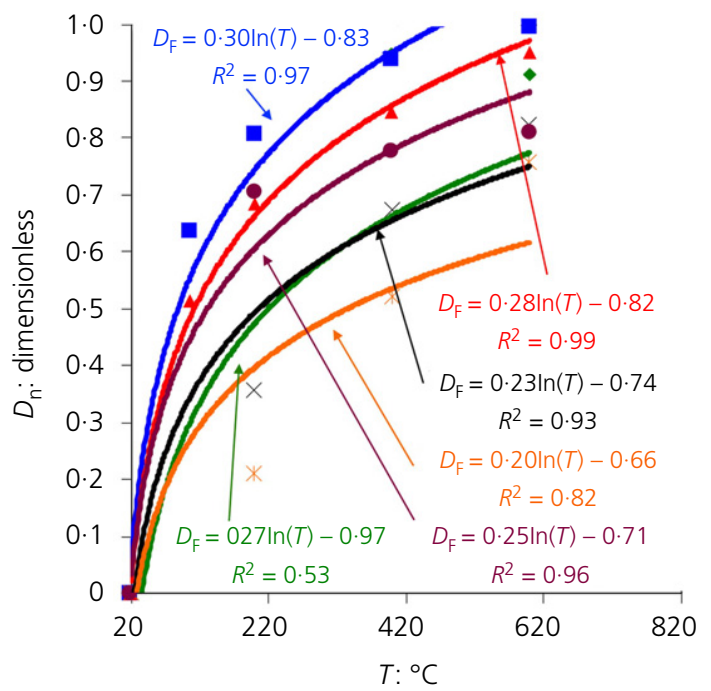

(b)

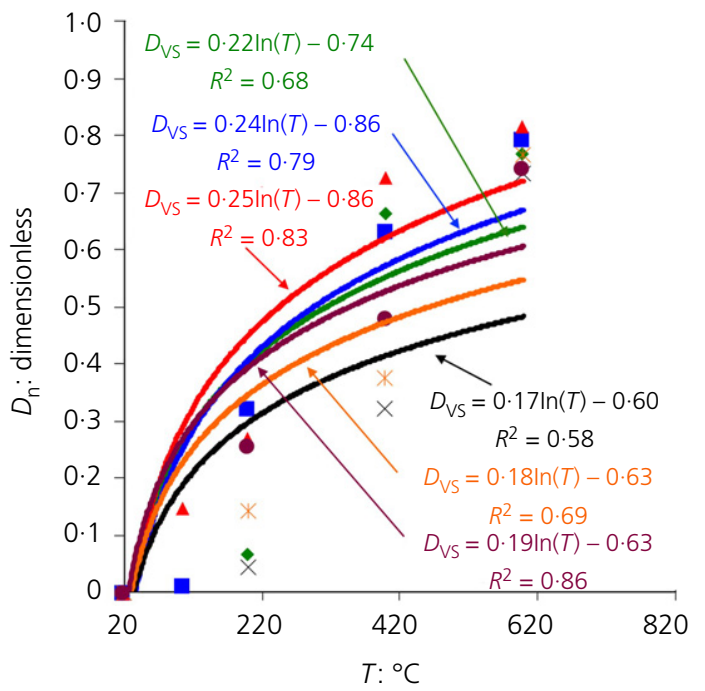

(d)

XBrazil_C * Brazil_D Brazil_SJ

Fig. 8. Relationship between the induced damage index for (a) porosity; (b) formation factor; (c) P- and (d) S-wave velocity and temperature

The variation of damage index with temperature is shown in Fig. 8 for each considered parameter. In general, damage indexes gradually increase with temperature following a logarithmic distribution. A dependence on the lithotype is also noticeable in terms of absolute values, while the relative trends remain comparable (Fig. 8). The most plausible explanation may be found in the interplay of bulk composition and strength (dolomitisation and/or grains recrystallisation) and degree of cementation.

The significance of the proposed damage index formulation for carbonatic rocks was assessed by comparing the experimental data with companion results available from literature (Ferrero \& Marini, 2000; Sengun, 2013; Yavuz et al., 2010; Brotóns et al., 2013; Zhang et al., 2017). Figure 9 shows the thermal damage trends for fine marble, coarse marble and dolomitic marble (respectively fuchsia dotted, continuous and dashed lines) and limestone (black continuous line) for $n$ (Fig. 9(a)) and $V_{\mathrm{P}}$ (Fig. 9(b)). The trends were evaluated by combining equation (2) (for $n$ ) and equation (3) (for $V_{\mathrm{P}}$ ) with equation (1) and considering $c$ equals to the fitting parameters shown in Fig. 2. It is possible to see that the experimental results obtained by the majority of the studies fall into these domains, proving the goodness of the proposed unified damage index. However, specific parameter calibration within the proposed limits should be performed for the different materials.

\section{CONCLUSIONS}

A series of laboratory tests on six, compositionally and texturally different, carbonate rocks was performed to investigate the variation of multiple physical parameters as a function of increasing temperature.

The main findings of this study can be summarised as

- In the range $200-400^{\circ} \mathrm{C}$, a turning point in the trend of physical behaviour is identified.

- The effect of temperature on physical properties depends mainly on rock texture, bulk composition and grain-size distribution resulting from the interplay of the primary processes of rock formation and recrystallisation.

In particular, if the rock was already naturally exposed to high temperatures, a stress memory is preserved and only minor changes in the physical parameters were detected 


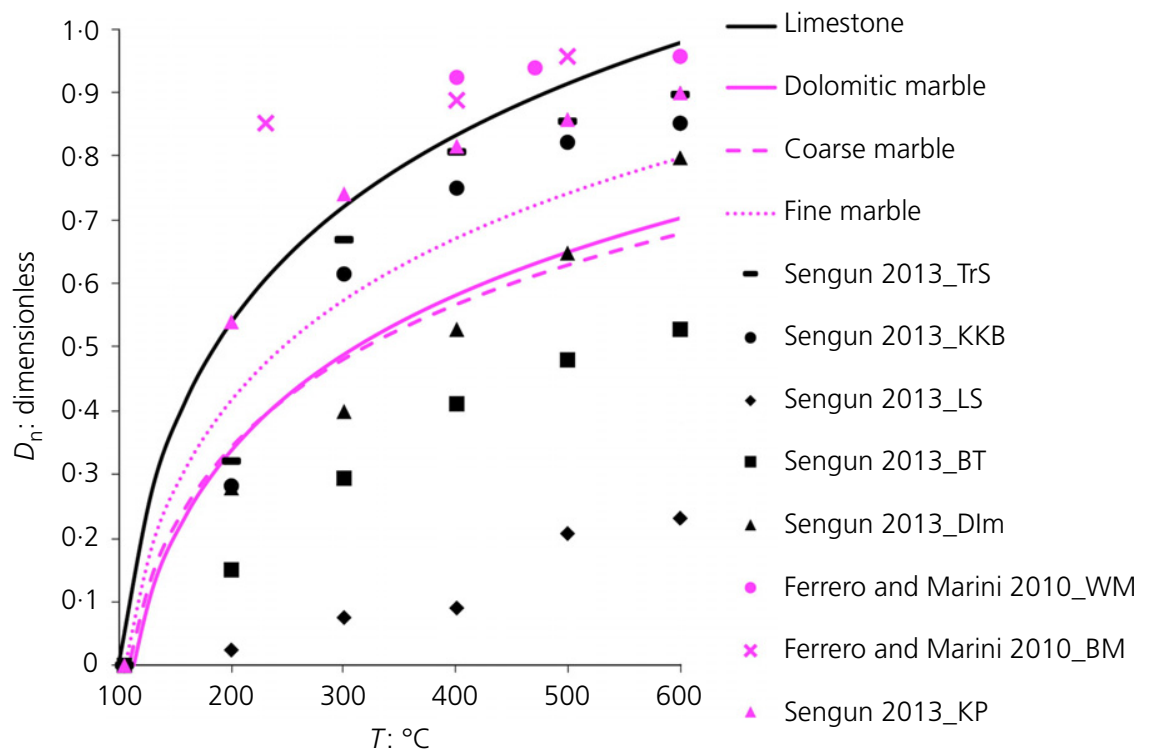

(a)

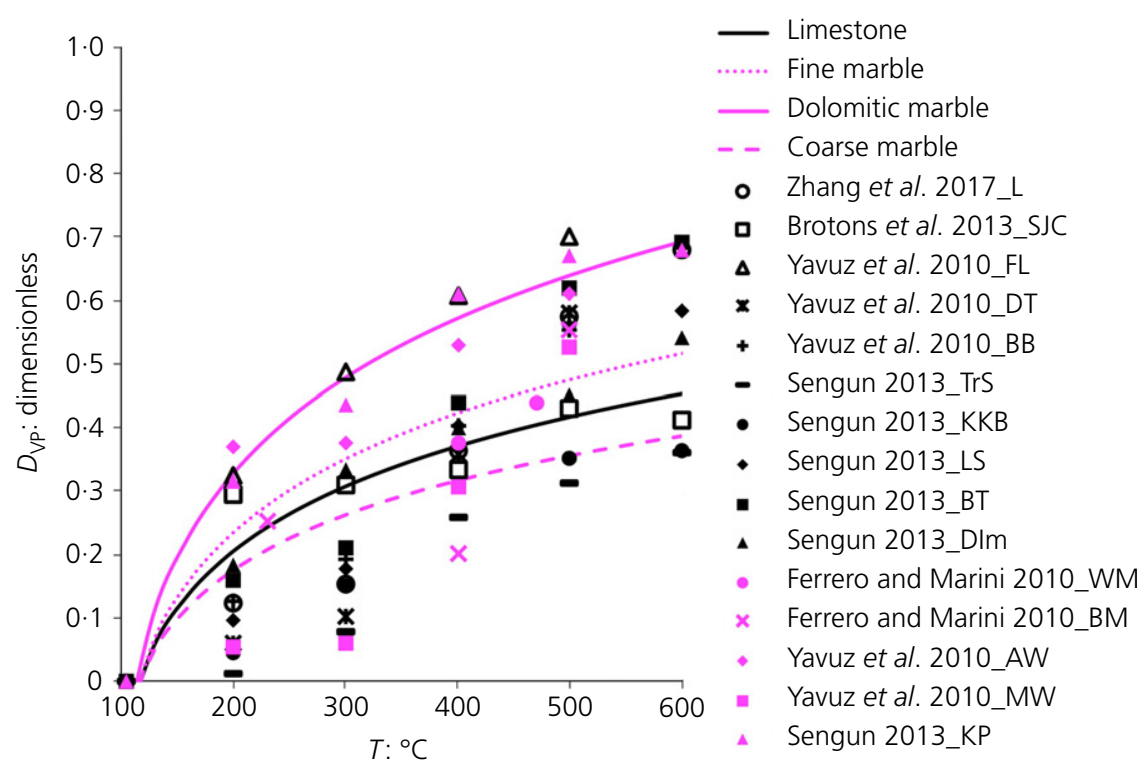

(b)

Fig. 9. Comparison between the proposed damage index and published results for porosity (a) and P-wave velocity (b). The results were grouped according to the rock type (black markers and lines for limestones and fuchsia for marbles). The acronym near the author's names stands for the material type (L: Linyi limestone; SJC: San Julian's calcarenite; FL: Finike Lymra limestone; DT: Denizli travertine; BB: Burdur Beige limestone; AW: Afyon White marble; MW: Mugla White marble; Dlm: Balikesir-Marmare Isaland Dolomitic limestone; TrS: Kayseri-Develi limestone; KKB: Burdur-Yesilova limestone; LS: Antalya-DEmre limestone; BT: Burdur-Bucak travertine; KP: Afyon-Ischisar marble; BM: Ormea Black marble; WM: Perlato Sicilia marble)

after thermal treatment. As a consequence, limestone samples exhibit a much higher thermal damage compared to marbles already exposed at high temperature and circulation of fluids at high temperature, especially in terms of porosity increase.

- A ubiquitous exponential relationship between physical parameter and temperature was found for each considered carbonate rock, where the exponent $c$ (equation (1)) can have positive or negative sign: o $\quad c=0.0044 \pm 0.003$ for limestone;

o $\quad c=0.0035 \pm 0.0021$ for fine grain marble;

o $\quad c=0.0026 \pm 0.0006$ for coarse grain marble; o $c=0 \cdot 0036 \pm 0 \cdot 001$ for dolomitic marble.

These coefficients were calculated as the average of the $c$ values of each rock set considered in this paper.
- A unified coefficient $D$ for quantifying the thermal damage of carbonate rocks has also been proposed and compared with available data from literature.

\section{CONFLICTS OF INTEREST}

The authors declare that there is no conflict of interest regarding the publication of this paper.

\section{FUNDING STATEMENT}

The study takes partial advantage from analyses (on Mexican samples) founded by the European Union's Horizon 2020 'GE-Mex' research and innovation program under the grant agreement number 727550 . 
Table 5. Summary of measured properties for the tested rocks.

\begin{tabular}{|c|c|c|c|c|c|c|c|c|c|c|c|c|c|c|}
\hline Set & Rock type & $T:{ }^{\circ} \mathrm{C}$ & $\begin{array}{c}\rho: \\
\mathrm{kg} / \mathrm{m}^{3}\end{array}$ & $\begin{array}{c}\sigma_{\mathrm{\rho}}: \\
\mathrm{kg} / \mathrm{m}^{3}\end{array}$ & $\begin{array}{c}\rho_{\text {wet }} \\
\mathrm{kg} / \mathrm{m}^{3}\end{array}$ & $\begin{array}{l}\sigma_{\text {pwet: }} \\
\mathrm{kg} / \mathrm{m}^{3}\end{array}$ & $\begin{array}{c}n: \\
\text { dimensionless }\end{array}$ & $\begin{array}{c}\sigma_{n}: \\
\text { dimensionless }\end{array}$ & $\begin{array}{l}V_{\mathrm{P}}: \\
\mathrm{m} / \mathrm{s}\end{array}$ & $\begin{array}{c}\sigma_{\mathrm{VP}}: \\
\mathrm{m} / \mathrm{s}\end{array}$ & $\begin{array}{l}V_{\mathrm{S}}: \\
\mathrm{m} / \mathrm{s}\end{array}$ & $\begin{array}{l}\sigma_{\mathrm{Vs}}: \\
\mathrm{m} / \mathrm{s}\end{array}$ & $\begin{array}{c}F: \\
\text { dimensionless }\end{array}$ & $\begin{array}{c}\sigma_{\mathrm{F}}: \\
\text { dimensionless }\end{array}$ \\
\hline \multirow[t]{4}{*}{ RLM } & \multirow[t]{4}{*}{ Limestone } & 20 & 2779 & 28 & 2778 & 28 & $0 \cdot 00105$ & $0 \cdot 00001$ & 5692 & 184 & 3220 & 45 & 1277 & 601 \\
\hline & & 200 & 2755 & 17 & 2736 & 17 & $0 \cdot 00336$ & $0 \cdot 00003$ & 6209 & 44 & 3007 & 21 & 1406 & 326 \\
\hline & & 400 & 2811 & 28 & 2843 & 28 & $0 \cdot 03203$ & $0 \cdot 00034$ & 2559 & 55 & 1079 & 40 & 65 & 6 \\
\hline & & 600 & 2754 & 21 & 2818 & 21 & $0 \cdot 06363$ & $0 \cdot 00047$ & 2267 & 134 & 743 & 22 & 111 & 9 \\
\hline \multirow[t]{5}{*}{ Valdieri } & \multirow[t]{5}{*}{ Marble } & 20 & 2712 & 15 & 2714 & 15 & $0 \cdot 00150$ & $0 \cdot 00002$ & 7500 & 87 & 4170 & 15 & 1200 & 148 \\
\hline & & 105 & 2712 & 16 & 2714 & 16 & $0 \cdot 00221$ & $0 \cdot 00001$ & 7382 & 131 & 4131 & 19 & 434 & 158 \\
\hline & & 200 & 2708 & 17 & 2712 & 17 & $0 \cdot 00405$ & $0 \cdot 00002$ & 4264 & 109 & 2831 & 40 & 228 & 76 \\
\hline & & 400 & 2710 & 19 & 2721 & 19 & $0 \cdot 01150$ & $0 \cdot 00008$ & 2275 & 34 & 1529 & 15 & 72 & 6 \\
\hline & & 600 & 2619 & 38 & 2648 & 39 & $0 \cdot 02854$ & $0 \cdot 00045$ & 1257 & 14 & 865 & 11 & 4 & 2 \\
\hline \multirow[t]{5}{*}{ GQ } & \multirow{5}{*}{$\begin{array}{c}\text { Dolomitic } \\
\text { marble }\end{array}$} & 20 & 2647 & 20 & 2650 & 20 & $0 \cdot 00528$ & $0 \cdot 00005$ & 5238 & 181 & 2863 & 23 & 497 & 132 \\
\hline & & 105 & 2640 & 30 & 2648 & 30 & $0 \cdot 00626$ & $0 \cdot 00006$ & 4482 & 162 & 2437 & 27 & 242 & 50 \\
\hline & & 200 & 2639 & 20 & 2648 & 20 & $0 \cdot 00931$ & $0 \cdot 00009$ & 3818 & 181 & 2087 & 84 & 156 & 18 \\
\hline & & 400 & 2632 & 30 & 2651 & 30 & $0 \cdot 01856$ & $0 \cdot 00020$ & 1308 & 58 & 782 & 48 & 76 & 13 \\
\hline & & 600 & 2618 & 30 & 2650 & 30 & $0 \cdot 03273$ & $0 \cdot 00038$ & 928 & 35 & 519 & 13 & 24 & 8 \\
\hline \multirow[t]{4}{*}{ Brazil C } & \multirow[t]{4}{*}{ Marble } & 20 & 2756 & 38 & 2801 & 38 & $0 \cdot 00349$ & $0 \cdot 00009$ & 5692 & 211 & 3151 & 152 & 838 & 237 \\
\hline & & 200 & 2751 & 37 & 2756 & 37 & $0 \cdot 00506$ & $0 \cdot 00010$ & 5623 & 105 & 3006 & 16 & 539 & 76 \\
\hline & & 400 & 2752 & 38 & 2762 & 38 & $0 \cdot 00989$ & $0 \cdot 00019$ & 4528 & 79 & 2139 & 21 & 271 & 85 \\
\hline & & 600 & 2735 & 38 & 2760 & 38 & $0 \cdot 02541$ & $0 \cdot 00051$ & 1819 & 136 & 836 & 16 & 146 & 67 \\
\hline \multirow{4}{*}{ Brazil D } & \multirow{4}{*}{ Marble } & 20 & 2851 & 40 & 2865 & 40 & $0 \cdot 00248$ & $0 \cdot 00005$ & 5750 & 644 & 2884 & 132 & 604 & 144 \\
\hline & & 200 & 2853 & 38 & 2857 & 38 & $0 \cdot 00392$ & $0 \cdot 00008$ & 5263 & 92 & 2471 & 76 & 478 & 99 \\
\hline & & 400 & 2823 & 38 & 2831 & 38 & $0 \cdot 00780$ & $0 \cdot 00014$ & 3736 & 105 & 1796 & 190 & 290 & 86 \\
\hline & & 600 & 2799 & 38 & 2844 & 39 & $0 \cdot 04523$ & $0 \cdot 00111$ & 1785 & 85 & 665 & 4 & 146 & 96 \\
\hline \multirow{4}{*}{$\begin{array}{c}\text { Brazil } \\
\text { SJ }\end{array}$} & \multirow[t]{4}{*}{ Marble } & 20 & 2878 & 39 & 2881 & 39 & $0 \cdot 00326$ & $0 \cdot 00006$ & 5780 & 179 & 3131 & 63 & 862 & 202 \\
\hline & & 200 & 2858 & 38 & 2867 & 38 & $0 \cdot 00834$ & $0 \cdot 00011$ & 4804 & 54 & 2335 & 30 & 252 & 23 \\
\hline & & 400 & 2853 & 38 & 2864 & 38 & $0 \cdot 01117$ & $0 \cdot 00016$ & 3931 & 53 & 1627 & 68 & 189 & 17 \\
\hline & & 600 & 2884 & 38 & 2917 & 39 & $0 \cdot 03270$ & $0 \cdot 00045$ & 1355 & 6 & 808 & 9 & 162 & 13 \\
\hline
\end{tabular}




\section{REFERENCES}

Ara, T. S., Talabani, S., Atlas, B., Vaziri, H. H. \& Islam, M. R. (2001). In-depth investigation of the validity of the Archie equation in carbonate rocks. In Proceedings - SPE production operations symposium, Oklahoma City, Oklahoma, pp. 177-183, https://doi.org/10.2523/67204-ms.

Archie, G. E. (1942). The electrical resistivity log as an aid in determining some reservoir characteristics. Trans. Am. Inst. Mech. Engrs 146, No. 1, 54-67.

Arganda-Carreras, I., Fernández-González, R., Muñoz-Barrutia, A. \& Ortiz-De-Solorzano, C. (2010). 3D Reconstruction of histological sections: application to mammary gland tissue. Microsc. Res. Technol. 73, No. 11, 1019-1029, https://doi.org/10.1002/jemt. 20829.

ASTM (2008). D 2845-08: Standard test method for laboratory determination of pulse velocities and ultrasonic elastic constants of rock (withdrawn 2017), ASTM International, West Conshohocken, PA, USA.

Brotóns, V., Tomás, R., Ivorra, I. \& Alarcón, J. C. (2013). Temperature influence on the physical and mechanical properties of a porous rock: San Julian's calcarenite. Engng Geol. 167, 117-127, https://doi.org/10.1016/j.enggeo.2013.10.012.

Castagna, A., Ougier-Simonin, A., Benson, P. M., Browning, J., Walker, R. J., Fazio, M. \& Vinciguerra, S. (2018). Thermal damage and pore pressure effects of the brittle-ductile transition in Comiso limestone. J. Geophys. Res. Solid Earth 123, No. 9, 7644-7660, https://doi.org/10.1029/2017JB015105.

Dwivedi, R. D., Goel, R. K., Prasad, V. V. R. \& Sinha, A. (2008). Thermo-mechanical properties of Indian and other granites. Int. J. Rock Mech. Min. Sci. 45, No. 3, 303-315, https://doi.org/ 10.1016/j.ijrmms.2007.05.008

Ferrero, A. M. \& Marini, P. (2000). Experimental studies on the mechanical behaviour of two thermal cracked marbles. Rock Mech. Rock Engng 34, No. 1, 57-66.

Heap, M. J., Mollo, S., Vinciguerra, S., Lavallée, Y., Baud, P., Dingwell, D. B., Iezzi, G. \& von Aulock, F. W. (2013). Thermal weakening of the carbonate basement under Mt. Etna volcano (Italy): implications for volcano instability. J. Volc. Geother. Res. 250, 42-60.

ISRM (1979). Suggested methods for determining water content, porosity, density absorption and related properties and swelling and slake-durability index properties. Int. J. Rock Mech. Min. Sci. 16, 141-156, https://doi.org/10.1016/0148-9062(79)91453-0.

Koca, M. Y., Ozden, G., Yavuz, A. B., Kincal, C., Onargan, T. \& Kucuk, K. (2006). Changes in the engineering properties of marble in fire-exposed columns. Int. J. Rock Mech. Min. Sci. 43, No. 4, 520-530, https://doi.org/10.1016/j.ijrmms.2005.09.007.

Musso, G., Cosentini, R. M., Foti, S., Comina, C. \& Capasso, G. (2015). Assessment of the structural representativeness of sample data sets for the mechanical characterization of deep formations. Geophysics 80, No. 5, D441-D457, https://doi. org/10.1190/GEO2014-0351.1.

Peng, J., Rong, G., Cai, M., Yao, M. D. \& Zhou, C. B. (2016). Physical and mechanical behaviours of a thermal-damaged coarse marble under uniaxial compression. Engng Geol. 200, 88-93.

Schneider, C. A., Rasband, W. S. \& Eliceiri, K. W. (2012). NIH Image to ImageJ: 25 years of image analysis. Nat. Methods $\mathbf{9}$, No. 7, pp. 671-675, https://doi.org/10.1038/nmeth.2089.

Sengun, N. (2013). Influence of thermal damage on the physical and mechanical properties of carbonate rocks. Arabian J. Geosci. 7, 5543-5514, https://doi.org/10.1007/s12517-013-1177-x.

Su, H., Jing, H., Yin, Q. \& Yu, L. (2018). Effect of thermal environment on the mechanical behaviors of building marble. Adv. Civil Engng, 2018, 1326503, https://doi.org/10.1155/2018/ 1326503.

Talabani, S., Boyd, D., El Wazeer, F. \& Al Arfi, S. (2000). Validity of Archie equation in carbonate rocks. In Society of petroleum engineers - Abu Dhabi international petroleum exhibition and conference, 2000, ADIPEC 2000, Abu Dhabi, United Arab Emirates, https://doi.org/10.2523/87302-ms.

Vagnon, F., Colombero, C., Colombo, F., Comina, C., Ferrero, A. M., Mandrone, G. \& Vinciguerra, S. C. (2019). Effects of thermal treatment on physical and mechanical properties of Valdieri marble - NW Italy. Int. J. Rock Mech. Min. Sci. 116, 75-86, https://doi.org/10.1016/j.ijrmms.2019.03. 006.

Weydt, L. M., Bär, K., Colombero, C., Comina, C., Deb, P., Lepillier, B., Mandrone, G., Milsch, H., Rochelle, C. A., Vagnon, F. \& Sass, I. (2018). Outcrop analogue study to determine reservoir properties of the Los Humeros and Acoculco geothermal fields, Mexico. Adv. Geosci. 45, 281-287, https://doi.org/10.5194/adgeo-45-281-2018.

Yavuz, A. B. \& Topal, T. (2007). Thermal and salt crystallization effects on marble deterioration: examples from Western Anatolia. Turkey Engng Geo. 90, No. 1-2, 30-40.

Yavuz, H., Demirdag, S. \& Caran, S. (2010). Thermal effect on the physical properties of carbonate rocks. Int. J. Rock Mech. Min. Sci. 47, No. 1, 94-103, https://doi.org/10.1016/j.ijrmms.2009.09. 014.

Zhao, Y., Wan, Z., Feng, Z., Yang, D., Zhang, Y. \& Qu, F. (2012). Triaxial compression system for rock testing under high temperature and high pressure. Int. J. Rock Mech. Min. Sci. 52, 132-138, https://doi.org/10.1016/j.ijrmms.2012.02.011.

Zhang, W., Sun, Q., Zhu, S. \& Wang, B. (2017). Experimental study on mechanical and porous characteristics of limestone affected by high temperature. Appl. Therm. Engng 110, 356-362, https:// doi.org/10.1016/j.applthermaleng.2016.08.194. 